\title{
Effect of Ethrel and Gibberelic Acid on Growth, Flowering, Sex Ratio and Yield to Luffa Plant
}

\author{
Magdy Azmy Barsoom ${ }^{1}$ and Mohamed A. Attala ${ }^{2}$
}

${ }^{1}$ Horticulture Research Institute, Agriculture Research Center, Giza, Egypt.

${ }^{2}$ Agricultural Economics Research Institute, Agriculture Research Center, Giza, Egypt.

Received: 30 Oct. 2020 / Accepted 15 Dec. 2020 / Publication date: 25 Dec. 2020

\begin{abstract}
The present field experiment was consummated throughout two successive seasons (2016/2017 and 2017/2018) at the nursery of Horticulture Research Institute, Agriculture Research Center, Giza, Egypt on Luffa cylindrical. The aim to study the effect of some growth regulators (ethrel and gibberellic acid) at different levels on growth, flowering and sex ratio of Luffa cylindrical on February $28^{\text {th }}$ in both seasons at $4 \mathrm{~m}$ distance between plants. After planting, the plants were treated with the first spray after two leaves grown, and the second spray was received after 4 leaves grown, then after that the plants were treated with spraying every 21 days until June $16^{\text {th }}$. The experiment was incorporated in randomized complete design with three replications and nine treatments viz 4 concentrations each of ethrel $(50,100,150$ and $200 \mathrm{ppm})$ and $\mathrm{GA}_{3}(100,150,200$ and $250 \mathrm{ppm})$ and control i.e. tap water spray were investigated. The results emphasized that, ethrel treatments especially at $100 \mathrm{ppm}$ showed beneficial effect on improving most plant traits in both seasons (stem length, stem diameter, No. of leaves/plant, No. of branches/plant, fruit length, fruit circumference and its yield). Meanwhile, $\mathrm{GA}_{3}$ gave was less effect on plant quality and in some instances caused a decrement on some plant parameters. The obtained results exert also the great effect of treating plants with ethrel at $100 \mathrm{ppm}$ for raising number of female flowers/plant, besides raising sex ratio. Also, the growth regulators used (ethrel and $\mathrm{GA}_{3}$ ) caused an improvement in chemical constituents of the newly formed plants (N, P and $\mathrm{K}$ and chlorophyll $\mathrm{a}, \mathrm{b}$ and carotenoids in both seasons). On the other hand, an economic feasibility study was made that was inferred through the economic evaluation of some economic indicators (total revenue per feddan, gross profit margin, ratio of total revenue to costs), which was calculated to evaluate the ethrel treatment at a concentration of $100 \mathrm{ppm}$ and found it was achieved positive results at the level of the indicators mentioned and also it was found that it achieved high productivity per acre compared to control and other transactions. From the results, it could be recommended to foliar spraying plants with ethrel at the level of $100 \mathrm{ppm}$ as such treatment proved its mastery in most cases on plant traits.
\end{abstract}

Keywords: Luffa cylindrical, Ethrel, Gibberellic acid $\left(\mathrm{GA}_{3}\right)$, Economic Feasibility

\section{Introduction}

Luffa cylindrica (Linn M. Roem), Family Cucurbitaceae is one of the important cucrbitaceous crop, grown extensively in India. The tender fruits are used as vegetable or as cooked vegetables. Besides, its use as vegetable, this gourd is utilized for various purposes (e.g. ornamental purposes, good pot holders, table mats, bathroom mats, slipper soles have been made out from the fibers). The sponge gourd Luffa cylindrica (Linn M. Roem) posses monoecious forms as well as a great diversity of the pistillate and staminate flowering ratio. In monoecious forms the production of staminate flower is far in excess of pistillate counter part. Since the yield of the crop depends upon the production of pistillate flowers, it is worth while to study the possibility of bringing about a shift in favour of sucf flowers, Sex ratio and thus increase the yield.

Plant growth regulators have profound influence on fruit production in cucurbits. It can modify growth and sex expression, improve fruit set and ultimately increase the yield in number of curbits. A relationship between growth substances and sex expression probably exists in these plants. Sex modification shift towards femaleness by exogenous application of auxin, gibberellins, growth retardants, other plant growth regulators $\left(\mathrm{PGR}_{\mathrm{s}}\right)\left(\mathrm{GA}_{3}\right.$ and ethrel) play an important role in morphology and physiology of the plants and influence on the plant growth and morphogenesis. They should be applied in optimal concentrations in stage of application, species specificity, seasons, etc. Also, they have important roles in many processes such as germination, seedling growth and product performance

Corresponding Author: Magdey A. Barsoom, Horticulture Research Institute, Agriculture Research Center, Giza, Egypt. 
and yield and ripening (Alkhassawnch et al., 2006). Accurately (Birader and Navalagatti, 2008) found that $\mathrm{PGR}_{\mathrm{s}}$ such as auxin and gibberellins include many aspects of plant growth and development. Seed priming with $\mathrm{PGR}_{\mathrm{s}}$ caused an increase in seed germination and seedling vigor (Chauhan et al., 2010; Jamil and Rha, 2007). In recent years, plant growth, flowering and yield have been manipulated with the help of growth regulating substances. Some $\mathrm{PGR}_{\mathrm{s}}$ have important effect on sex expression in various cucurbitaceons crops. Also, by decreasing the male or female flowers, it causes change in yield (Hilli and Vyakaranahal, 2005). $\mathrm{PGR}_{\mathrm{s}}$ are chemical materials that are used in low concentration to change the growth of plant usually by stimulating part of the natural growth regulators system. Ethrel spray at 400 $\mathrm{ppm}$ in four to six leaf stage significantly increased the number of female flowers per plant $(35.23 \%)$ and reduced the sex ratio (3.69) compared to control (19.8 and 224.5 respectively) in cucumber (Vadigeri et al., 2001). Ethrel at 100 ppm enhanced the total yield cucumber (Thappa et al., 2011). Trailing method plays very important role in growth and quality of Cucurbitaceae family crops. Part et al. (2008) reported that $\mathrm{GA}_{3}$ increased the growth and quality of characteristics and total flowering of jujube. Asrey et al. (2001) studied the effect of seed priming with $\mathrm{GA}_{3}$ on growth and fruiting in muskmelon and reported that $\mathrm{GA}_{3}$ at $400 \mathrm{ppm}$ significantly enhanced the yield when compared to control. . Ethrel at 300 and $500 \mathrm{ppm}$ had little effect on 1000 seed weight and seed germination was not influenced by ethrel in Cucurbita maxima (Korzeniewska and Niemirowiez, 1993). Gad et al. (1993) showed that ethrel at 225 or $300 \mathrm{ppm}$ was very effective on summer squash sex expression and enhanced number of fruit per plant and total yields.

\section{Materials and Methods}

The present experiments was consummated throughout two successive seasons (2016/2017 and 2017/2018) at the nursery of Ornamental Plant and Landscape Department, Horticulture Research Institute, Agriculture Research Center, Giza, Egypt with the aim to study the effect of some growth regulators (ethrel and gibberellic acid) at different levels (ethrel at 50, 100, 150 and $200 \mathrm{ppm}$ ) and $\left(\mathrm{GA}_{3}\right.$ at 100, 150200 and $250 \mathrm{ppm}$ ) and control (i.e. tap water spray). The seeds were planted on February $28^{\text {th }}$ in both seasons at $4 \mathrm{~m}$ apart and the growth regulators were applied as a foliar spray every 21 days commencing from $2^{\text {nd }}$ and $4^{\text {th }}$ leaf stage till June $16^{\text {th }}$ in the two seasons. The experiment was incorporated in randomized complete design (RCD) with three replications and nine treatments viz, four concentration each of ethrel (50,100,150 and $200 \mathrm{ppm})$ and $\mathrm{GA}_{3}(100,150200$ and $250 \mathrm{ppm})$ and control (i.e. tap water spray) were investigated.

Data collected were on vegetative growth parameters, fruit parameters (stem length $(\mathrm{cm}$.$) , stem$ diameter (cm.), No. of leaves/plant, No. of branches/plant, fruit length $(\mathrm{cm}$.$) , fruit circumference (\mathrm{cm}$.$) ,$ fruit weight (g.), No. of seeds/fruit, weight of seeds/fruit (g.), No. of fruits/plant, leaf area $\left(\mathrm{cm}^{2}\right)$, number of days from planting to flowering, No. of male flowers, No. of female/flowers and sex ratio\% were also estimated. needed.

Regular agricultural practices such as weeding, watering... etc were carried out whenever

Chemical constituents of the plant were determined as nitrogen (Blake, 1965), phosphorus (John, 1970), and potassium (Dewis and Freitas, 1970).

Photosynthetic pigments content (chlorophyll $\mathrm{a}, \mathrm{b}$ and carotenoids $\mathrm{mg} / \mathrm{g}$.f.w.) were determined according to the methods of Saric et al. (1976)

Data were statistically analyzed using SAS program (1994) and means of were compared by L.S.D. test at 5\% level of probability (Snedecor and Cochran, 1980).

\section{Results}

All growth regulators treatments caused an improving in plant parameters comparing with that gained from control treatment in the two seasons.

\section{- Growth characters:}

1- Effect of ethrel and $\mathrm{GA}_{3}$ on stem parametes:

a- Effect of ethrel and $\mathrm{GA}_{3}$ on stem length:

Insignificant effects were observed in stem length due to the application of the different ethrel or $\mathrm{GA}_{3}$ treatments on such traits in both seasons as indicated in Table (1). 


\section{b- Effect of ethrel and $\mathrm{GA}_{3}$ on stem diameter:}

As shown from data outlined in Table (1), using ethrel at $100 \mathrm{ppm}$ proved its mastery in producing the thickest stem in the two seasons. However, receiving plants $\mathrm{GA}_{3}$ at $250 \mathrm{ppm}$ recorded the lowest means in both seasons. Meanwhile, the other treatments gave an intermediate effects in this concern.

Table 1: Effect of ethrel and gibberellic acid on stem length $(\mathrm{cm}$.$) and stem diameter (\mathrm{cm}$.) of Luffa cylindrica during the two seasons (2016/2017 and 2017/2018)

\begin{tabular}{|c|c|c|c|c|}
\hline & \multicolumn{2}{|c|}{ Stem length (cm.) } & \multicolumn{2}{|c|}{ Stem diameter (cm.) } \\
\hline & $1^{\text {st }}$ Season & $2^{\text {nd }}$ Season & $1^{\text {st }}$ Season & $2^{\text {nd }}$ Season \\
\hline Control & 180 & 208 & 1.10 & 1.18 \\
\hline Ethrel 50 ppm & 265 & 320 & 1.30 & 1.42 \\
\hline Ethrel 100 ppm & 280 & 315 & 1.53 & 1.62 \\
\hline Ethrel 150 ppm & 273 & 307 & 1.17 & 1.29 \\
\hline Ethrel 200 ppm & 230 & 327 & 1.47 & 1.53 \\
\hline $\mathrm{GA}_{3} 100$ ppm & 277 & 342 & 1.20 & 1.33 \\
\hline $\mathrm{GA}_{3} 150 \mathrm{ppm}$ & 242 & 276 & 1.43 & 1.54 \\
\hline GA3 200 ppm & 210 & 234 & 1.23 & 1.39 \\
\hline $\mathrm{GA}_{3} 250 \mathrm{ppm}$ & 225 & 275 & 1.16 & 1.25 \\
\hline LSD at 0.05 & 11.962 & 12.358 & 0.235 & 0.358 \\
\hline
\end{tabular}

2- Effect of ethrel and $\mathrm{GA}_{3}$ on No. of leaves/plant and No. of branches/plant:

a- Effect of ethrel and $\mathrm{GA}_{3}$ on No. of leaves/plant

Evidently, data scored in Table (2) indicate the prevalence of receiving plants the lowest level of ethrel (50 ppm), with significant effect in the two seasons. In contrast, the lowest means were gained as a result of applying $\mathrm{GA}_{3}$ at $200 \mathrm{ppm}$ in the first season or applying $\mathrm{GA}_{3}$ treatments at either $150 \mathrm{ppm}$ or at $250 \mathrm{ppm}$ in the second one.

\section{b- Effect of ethrel and $\mathrm{GA}_{3}$ on No. of branches/plant:}

Great influence on No. of branches/plant with significant effect was observed in the two seasons due to applying ethrel treatment at $50 \mathrm{ppm}$ comparing with that gained from the other treatments used in this respect. On the contrary, considerable decrease in number of branches/plant was noticed in both seasons due to treating plants with $\mathrm{GA}_{3}$ at $250 \mathrm{ppm}$ as mentioned in Table (2).

Table 2: Effect of ethrel and gibberellic acid on No. of leaves/plant and No. of branch/plant of Luffa cylindrica during the two seasons (2016/2017 and 2017/2018)

\begin{tabular}{lcccc}
\hline & \multicolumn{2}{c}{ No. of leaves/plant } & \multicolumn{2}{c}{ No. of branch/plant } \\
\cline { 2 - 5 } Treatments & $\mathbf{1}^{\text {st }}$ Season & $\mathbf{2}^{\text {nd }}$ Season & $\mathbf{1}^{\text {st }}$ Season & $\mathbf{2}^{\text {nd }}$ Season \\
\hline Control & 19.00 & 20.00 & 1.2 & 1.4 \\
Ethrel $\mathbf{5 0} \mathbf{~ p p m}$ & 32.00 & 46.50 & 6.2 & 7.8 \\
Ethrel $\mathbf{1 0 0} \mathbf{~ p p m}$ & 31.00 & 43.00 & 5.5 & 6.5 \\
Ethrel $\mathbf{1 5 0} \mathbf{~ p p m}$ & 28.00 & 30.00 & 4.3 & 5.6 \\
Ethrel $\mathbf{2 0 0} \mathbf{~ p p m}$ & 29.00 & 32.50 & 4.5 & 5.8 \\
$\mathbf{G A}_{3} \mathbf{1 0 0} \mathbf{~ p p m}$ & 28.50 & 30.50 & 3.5 & 4.3 \\
$\mathbf{G A}_{3} \mathbf{1 5 0} \mathbf{~ p p m}$ & 27.00 & 28.50 & 2.5 & 3.4 \\
$\mathbf{G A}_{3} \mathbf{2 0 0} \mathbf{~ p p m}$ & 22.00 & 29.50 & 2.3 & 2.5 \\
$\mathbf{G A}_{3} \mathbf{2 5 0} \mathbf{~ p p m}$ & 23.50 & 28.50 & 1.5 & 1.7 \\
LSD at $\mathbf{0 . 0 5}$ & 0.961 & 1.523 & 3.852 & 4.153 \\
\hline
\end{tabular}




\section{3- Effect of ethrel and $\mathrm{GA}_{3}$ on fruit parameters:}

\section{a- Effect of ethrel and $\mathrm{GA}_{3}$ on fruit length:}

Considerable increment in fruit length was observed in the two seasons as a result of receiving plant ethrel treatment at the level of $100 \mathrm{ppm}$. However, the opposite was right as a result of supplying plants the highest level of $\mathrm{GA}_{3}$ at $50 \mathrm{ppm}$ in the two seasons. The other treatments, on the other side gave intermediate effects on such trait in both seasons, as indicated in Table (3).

\section{b-Effect of ethrel and $\mathrm{GA}_{3}$ on fruit circumference:}

Obviously, data exhibited in Table (3) confirm the superiority of using ethrel at $50 \mathrm{ppm}$ in raising fruit circumference in the two seasons. Meanwhile, the opposite was right on such trait due to using $\mathrm{GA}_{3}$ at $250 \mathrm{ppm}$ in the two seasons, as this treatment gave the lowest means in this regard. The other treatments, on the other side, gave an intermediate effect in this respect.

\section{c- Effect of ethrel and $\mathrm{GA}_{3}$ on fruit weight:}

As shown from data presented in Table (3) applying $\mathrm{GA}_{3}$ at $100 \mathrm{ppm}$ considerably increased fruit weight comparing with that gained from the most other treatments applied in the two seasons. In contrast, receiving plants ethrel at $50 \mathrm{ppm}$ gave the lowest means in this respect.

Table 3: Effect of ethrel and gibberellic acid on fruit length $(\mathrm{cm}$.), fruit circumference $(\mathrm{cm}$.) and fruit weight (g.) of Luffa cylindrica during the two seasons (2016/2017 and 2017/2018)

\begin{tabular}{|c|c|c|c|c|c|c|}
\hline \multirow[b]{2}{*}{ Treatments } & \multicolumn{2}{|c|}{$\begin{array}{c}\begin{array}{c}\text { Fruit length } \\
(\mathrm{cm})\end{array} \\
\end{array}$} & \multicolumn{2}{|c|}{$\begin{array}{c}\text { Fruit circumference } \\
(\mathbf{c m})\end{array}$} & \multicolumn{2}{|c|}{$\begin{array}{l}\text { Fruit weight } \\
\text { (g) }\end{array}$} \\
\hline & $1^{\text {st }}$ Season & $2^{\text {nd }}$ Season & $1^{\text {st }}$ Season & $2^{\text {nd }}$ Season & $1^{\text {st }}$ Season & $2^{\text {nd }}$ Season \\
\hline Control & 20.00 & 22.00 & 20.00 & 22.00 & 38.00 & 42.00 \\
\hline Ethrel 50 ppm & 34.00 & 37.00 & 32.00 & 43.00 & 45.00 & 47.00 \\
\hline Ethrel 100 ppm & 36.50 & 41.00 & 29.00 & 41.00 & 46.50 & 59.50 \\
\hline Ethrel 150 ppm & 32.00 & 35.00 & 27.00 & 33.00 & 48.00 & 58.00 \\
\hline Ethrel 200 ppm & 30.00 & 34.00 & 26.50 & 30.00 & 62.00 & 75.00 \\
\hline $\mathrm{GA}_{3} 100$ ppm & 29.00 & 32.00 & 24.50 & 27.00 & 98.00 & 110.00 \\
\hline $\mathrm{GA}_{3} 150 \mathrm{ppm}$ & 27.00 & 30.00 & 23.50 & 25.00 & 73.00 & 88.50 \\
\hline $\mathrm{GA}_{3} 200 \mathrm{ppm}$ & 25.50 & 27.00 & 23.00 & 24.00 & 52.50 & 69.51 \\
\hline $\mathrm{GA}_{3} 250 \mathrm{ppm}$ & 23.00 & 25.00 & 22.00 & 23.00 & 58.50 & 79.50 \\
\hline LSD at 0.05 & 5.602 & 6.120 & 4.980 & 5.053 & 5.786 & 6.223 \\
\hline
\end{tabular}

\section{4- Effect of ethrel and $\mathrm{GA}_{3}$ on No. of days from planting to flowering:}

It is clear from data outlined in Table (4) that plants which treated with $\mathrm{GA}_{3}$ at $250 \mathrm{ppm}$ took the longest period to flower in the two seasons, comparing with that gained from the other treatments. However, the opposite was right for that recorded from plants treated with ethrel at $100 \mathrm{ppm}$ in both seasons, as they recorded the shortest period for flowering.

\section{5- Effect of ethrel and $\mathrm{GA}_{3}$ on Leaf area:}

Data presented in Table (4) indicate the superiority of applying ethrel at $200 \mathrm{ppm}$ for obtaining the highest value of leaf area in both seasons. However, the opposite was right for receiving plant $\mathrm{GA}_{3}$ at $200 \mathrm{ppm}$, which gave the least score in this concern in both seasons.

\section{6- Effect of ethrel and $\mathrm{GA}_{3}$ on fruit yield:}

Data exhibited in Table (4) exert the beneficial effect of applying either ethrel or $\mathrm{GA}_{3}$ in raising No. of fruits/plant in both seasons, comparing with that gained from untreated plants (control). In this connection applying ethrel at $100 \mathrm{ppm}$ was the best treatment used for increasing No. of fruits/plant with significant effect in the two seasons, followed by that gained from using ethrel at 150 and $200 \mathrm{ppm}$ in both seasons. Meanwhile, all $\mathrm{GA}_{3}$ levels succeeded also to increase No. of fruits/plant over control but with less effect comparing with that obtained from ethrel treatments in the two seasons. 
The previous results indicated the great economic values resulted from using the different growth regulators of either ethrel or $\mathrm{GA}_{3}$ with the mastery of applying ethrel in raising No. of fruits/plant (fruits yield) in the two seasons.

Table 4: Effect of ethrel and gibberellic acid on number of days from planting to flowering, leaf area $\left(\mathrm{cm}^{2}\right)$ and No. fruit/plant ( fruit yield) of Luffa cylindrica during the two seasons (2016/2017 and 2017/2018)

\begin{tabular}{lcccccc}
\hline \multirow{2}{*}{ Treatments } & \multicolumn{2}{c}{$\begin{array}{c}\text { Number of days from } \\
\text { planting to flowering }\end{array}$} & \multicolumn{2}{c}{$\begin{array}{c}\text { Leaf area } \\
\left(\mathbf{c m}^{\mathbf{2}}\right)\end{array}$} & \multicolumn{2}{c}{$\begin{array}{c}\text { No. fruit/plant } \\
\text { (fruit yield) }\end{array}$} \\
\cline { 2 - 7 } & $\mathbf{1}^{\text {st }}$ Season & $\mathbf{1}^{\text {st }}$ Season & $\mathbf{1}^{\text {st }}$ Season & $\mathbf{2}^{\text {nd }}$ Season & $\mathbf{1}^{\text {st }}$ Season & $\mathbf{2}^{\text {nd }}$ Season \\
\hline Control & 80.6 & 82.4 & 191.56 & 205.06 & 12.50 & 13.31 \\
Ethrel 50 ppm & 82.5 & 84.7 & 268.96 & 290.91 & 23.52 & 24.26 \\
Ethrel 100 ppm & 78.0 & 80.5 & 225.00 & 244.12 & 24.31 & 25.08 \\
Ethrel 150 ppm & 86.7 & 88.3 & 256.00 & 284.93 & 22.30 & 23.41 \\
Ethrel 200 ppm & 89.4 & 91.5 & 290.36 & 316.56 & 20.57 & 22.23 \\
GA3 100 ppm & 86.2 & 88.6 & 163.84 & 188.02 & 18.18 & 20.71 \\
GA3 $\mathbf{1 5 0} \mathbf{~ p p m}$ & 88.6 & 90.4 & 208.28 & 228.37 & 17.22 & 19.43 \\
GA3 200 ppm & 87.2 & 89.5 & 145.93 & 165.69 & 15.82 & 16.52 \\
GA3 250 $\mathbf{~ p p m ~}$ & 92.4 & 94.2 & 186.05 & 206.90 & 13.90 & 14.42 \\
LSD at 0.05 & 2.055 & 3.131 & 6.245 & 7.362 & 1.912 & 2.533 \\
\hline
\end{tabular}

7- Effect of ethrel and $\mathrm{GA}_{3}$ on seeds parameters:

a- Effect of ethrel and $\mathrm{GA}_{3}$ on number of seeds/fruit

As indicated from data outlined in Table (5), supplying plants $\mathrm{GA}_{3}$ at $100 \mathrm{ppm}$ was the best treatment used in raising number of seeds/fruit in the two seasons. The opposite was right, where ethrel was applied at $100 \mathrm{ppm}$ in the two seasons as they gave the least number of seeds/fruit in the two seasons.

\section{b- Effect of ethrel and $\mathrm{GA}_{3}$ on weight of seeds/fruit:}

Evidently, data registered in Table (5), show the superiority of applying ethrel at $200 \mathrm{ppm}$ in the two seasons, for obtaining the highest values in the two seasons. On the contrary, receiving plant ethrel at $100 \mathrm{ppm}$ in the first season and $50 \mathrm{ppm}$ in the second one were the poorest treatments for the effect of the different growth regulators treatments on weight of seeds of fruits in both seasons. However, the other treatments gave intermediate effects in this regard.

Table 5: Effect of ethrel and gibberellic acid on No. of seeds/fruit and weight of seeds/fruit (g.) of Luffa cylindrica during the two seasons (2016/2017 and 2017/2018).

\begin{tabular}{|c|c|c|c|c|}
\hline \multirow[b]{2}{*}{ Treatments } & \multicolumn{2}{|c|}{ No. of seeds/fruit } & \multicolumn{2}{|c|}{ Weight of seeds/fruit (g.) } \\
\hline & $1^{\text {st }}$ Season & $2^{\text {nd }}$ Season & $1^{\text {st }}$ Season & $2^{\text {nd }}$ Season \\
\hline Control & 130.0 & 160.0 & 13.00 & 17.80 \\
\hline Ethrel 50 ppm & 141.0 & 168.0 & 28.50 & 23.00 \\
\hline Ethrel 100 ppm & 132.0 & 163.5 & 23.00 & 25.00 \\
\hline Ethrel 150 ppm & 145.0 & 189.0 & 25.00 & 27.50 \\
\hline Ethrel 200 ppm & 178.0 & 209.5 & 30.50 & 32.00 \\
\hline GA3 100 ppm & 193.0 & 259.0 & 29.00 & 31.00 \\
\hline $\mathrm{GA}_{3} 150 \mathrm{ppm}$ & 164.0 & 212.0 & 27.50 & 29.50 \\
\hline $\mathrm{GA}_{3} 200$ ppm & 143.0 & 187.5 & 24.00 & 26.50 \\
\hline $\mathrm{GA}_{3} 250 \mathrm{ppm}$ & 189.0 & 229.5 & 26.50 & 28.00 \\
\hline LSD at 0.05 & 1.962 & 2.035 & 1.612 & 1.832 \\
\hline
\end{tabular}


8- Effect of ethrel and $\mathrm{GA}_{3}$ on flowering behavior:

a- Effect of ethrel and $\mathrm{GA}_{3}$ on No. of male flowers/plant:

Obviously, data exhibited in Table (6) showed the superiority of treating plants with ethrel at the level of $100 \mathrm{ppm}$ as it was the best treatment used in both seasons, as the highest values were obtained in this respect. However, the lowest records were obtained as a result of applying $\mathrm{GA}_{3}$ at $250 \mathrm{ppm}$ in both seasons.

\section{b- Effect of ethrel and $\mathrm{GA}_{3}$ on No. of female flowers/plant:}

Data exhibited in Table (6) exert the beneficial effect of treating plants with ethrel at $100 \mathrm{ppm}$ for raising number of female flowers plant in both seasons. Meanwhile, the lowest values of female flowers were a result of receiving plants $\mathrm{GA}_{3}$ at $250 \mathrm{ppm}$. The other treatments on the other hand, gave intermediate effects in both seasons.

\section{c- Effect of ethrel and $\mathrm{GA}_{3}$ on Sex ratio:}

Data presented in Table (6) showed the beneficial effect of supplying plants with ethrel treatment at $100 \mathrm{ppm}$ in raising sex ratio value as such treatment gave rise to the utmost highest values in both seasons. In contrast, the least scores of sex ratio were a result of treating plants with $\mathrm{GA}_{3}$ at $250 \mathrm{ppm}$ in the two seasons.

Table 6: Effect of ethrel and gibberellic acid on male flowers, female flowers and sex ratio\% of Luffa cylindrica during the two seasons (2016/2017 and 2017/2018)

\begin{tabular}{|c|c|c|c|c|c|c|}
\hline \multirow[b]{2}{*}{ Treatments } & \multicolumn{2}{|c|}{ Male flowers } & \multicolumn{2}{|c|}{ Female flowers } & \multicolumn{2}{|c|}{ Sex ratio (\%) } \\
\hline & $1^{\text {st }}$ Season & $2^{\text {nd }}$ Season & $1^{\text {st }}$ Season & $2^{\text {nd }}$ Season & $1^{\text {st }}$ Season & $2^{\text {nd }}$ Season \\
\hline Control & 231.00 & 232.50 & 12.71 & 13.94 & $5.5 \%$ & $6.0 \%$ \\
\hline Ethrel 50 ppm & 296.40 & 308.47 & 36.45 & 40.71 & $12.3 \%$ & $13.2 \%$ \\
\hline Ethrel 100 ppm & 300.83 & 320.70 & 40.61 & 46.50 & $13.5 \%$ & $14.5 \%$ \\
\hline Ethrel 150 ppm & 290.62 & 303.62 & 34.29 & 37.98 & $11.8 \%$ & $12.5 \%$ \\
\hline Ethrel 200 ppm & 279.50 & 295.05 & 30.78 & 34.50 & $11.0 \%$ & $11.7 \%$ \\
\hline GA3 100 ppm & 264.30 & 278.32 & 27.75 & 32.28 & $10.5 \%$ & $11.6 \%$ \\
\hline $\mathrm{GA}_{3} 150 \mathrm{ppm}$ & 251.25 & 265.39 & 24.12 & 27.37 & $9.6 \%$ & $10.3 \%$ \\
\hline $\mathrm{GA}_{3} 200 \mathrm{ppm}$ & 243.11 & 255.90 & 21.39 & 24.05 & $8.8 \%$ & $9.4 \%$ \\
\hline $\mathrm{GA}_{3} 250$ ppm & 232.35 & 246.69 & 19.09 & 20.96 & $8.2 \%$ & $8.5 \%$ \\
\hline LSD at 0.05 & 10.334 & 11.210 & 7.355 & 8.562 & 1.834 & 1.955 \\
\hline
\end{tabular}

\section{9- Effect of ethrel and $\mathrm{GA}_{3}$ on Pigments content:}

Data presented in Table (7) indicate the prevalence of treating plant with Ethrel at $200 \mathrm{ppm}$ for raising pigments content in both seasons, comparing with that gained from the other growth regulators used in both seasons. Meanwhile, the lowest records were a result of plants treated with ethrel at 50 ppm for chlorophyll (a) and 150 ppm of ethrel for chlorophyll (b) and carotenoids.

Table 7: Effect of ethrel and gibberellic acid on chlorophyll a, b and carotienods (mg/g.f.w.) of Luffa cylindrica during the two seasons (2016/2017 and 2017/2018)

\begin{tabular}{lcccccc}
\hline & \multicolumn{2}{c}{ Chlorophyll a } & \multicolumn{2}{c}{ Chlorophyll b } & \multicolumn{2}{c}{ Carotienods } \\
Treatments & $\mathbf{1}^{\text {st }}$ Season & $\mathbf{2}^{\text {nd }}$ Season & $\mathbf{1}^{\text {st }}$ Season & $\mathbf{2}^{\text {nd }}$ Season & $\mathbf{1}^{\text {st }}$ Season & $\mathbf{2}^{\text {nd }}$ Season \\
\hline Control & 0.324 & 0.437 & 0.146 & 0.153 & 0.231 & 0.252 \\
Ethrel 50 ppm & 0.431 & 0.542 & 0.151 & 0.162 & 0.276 & 0.281 \\
Ethrel 100 ppm & 0.633 & 0.678 & 0.182 & 0.189 & 0.282 & 0.287 \\
Ethrel 150 ppm & 0.711 & 0.752 & 0.131 & 0.138 & 0.192 & 0.199 \\
Ethrel 200 ppm & 0.823 & 0.902 & 0.197 & 0.199 & 0.290 & 0.296 \\
GA3 100 ppm & 0.615 & 0.645 & 0.164 & 0.171 & 0.250 & 0.265 \\
GA3 150 ppm & 0.522 & 0.580 & 0.156 & 0.166 & 0.255 & 0.240 \\
GA3 200 ppm & 0.743 & 0.886 & 0.187 & 0.190 & 0.261 & 0.282 \\
GA3 250 ppm & 0.689 & 0.705 & 0.174 & 0.181 & 0.254 & 0.270 \\
\hline
\end{tabular}




\section{0- Effect of ethrel and $\mathrm{GA}_{3}$ on Chemical constituents:}

Data exhibited on the effect of the different growth regulators of different levels revealed the increment of $\mathrm{N} \%$ due to applying $\mathrm{GA}_{3}$ at $150 \mathrm{ppm}$ in the first season and with applying ethrel at 100 $\mathrm{ppm}$ in the second one. However, the highest values of $\mathrm{P} \%$ was a result of receiving plants $\mathrm{GA}_{3}$ at 100 ppm in both seasons. Meanwhile, the highest values of $\mathrm{K} \%$ was a result of applying ehtrel at $50 \mathrm{ppm}$ in both season.

Table 8: Effect of ethrel and gibberellic acid on nitrogen, phosphours and potassium $\%$ of $L u f f a$ cylindrica during the two seasons (2016/2017 and 2017/2018)

\begin{tabular}{lcccccc}
\hline & \multicolumn{2}{c}{$\mathbf{N} \%$} & \multicolumn{2}{c}{$\mathbf{~} \%$} & \multicolumn{2}{c}{ K\% } \\
\cline { 2 - 7 } \multicolumn{1}{c}{ Treatments } & $\mathbf{1}^{\text {st }}$ Season & $\mathbf{2}^{\text {nd }}$ Season & $\mathbf{1}^{\text {st }}$ Season & $\mathbf{2}^{\text {nd }}$ Season & $\mathbf{1}^{\text {st }}$ Season & $\mathbf{2}^{\text {nd }}$ Season \\
\hline Control & 3.356 & 3.865 & 0.458 & 0.489 & 0.925 & 1.053 \\
Ethrel 50 ppm & 3.791 & 4.035 & 0.653 & 0.703 & 1.206 & 1.432 \\
Ethrel 100 ppm & 3.964 & 4.324 & 0.320 & 0.478 & 0.837 & 0.978 \\
Ethrel 150 ppm & 3.569 & 4.153 & 0.545 & 0.598 & 1.232 & 1.786 \\
Ethrel 200 ppm & 2.827 & 3.436 & 0.537 & 0.576 & 0.947 & 1.108 \\
$\mathbf{G A}_{3} \mathbf{1 0 0} \mathbf{~ p p m}$ & 2.881 & 3.633 & 0.546 & 0.582 & 1.341 & 1.812 \\
$\mathbf{G A}_{3} \mathbf{1 5 0} \mathbf{~ p p m}$ & 4.061 & 4.267 & 0.315 & 0.453 & 0.857 & 1.033 \\
$\mathbf{G A 3}_{3} \mathbf{2 0 0} \mathbf{~ p p m}$ & 2.756 & 3.124 & 0.364 & 0.475 & 0.785 & 0.958 \\
$\mathbf{G A}_{3} \mathbf{2 5 0} \mathbf{~ p p m}$ & 2.636 & 3.025 & 0.607 & 0.712 & 1.122 & 1.352 \\
\hline
\end{tabular}

\section{Discussion}

The aforementioned results of the morphological traits may lead to the following: Patel et al. (2009) experimented the effect of ethrel on sex ratio of Luffa cylindrica. They concluded that the response of different concentrations of ethrel on number of male flowers, number of female flowers and sex ratio was found significant when compared to control. The reduced level of endogenous gibberellins and increased level of auxin after ethrel spray was reported by Rudinch et al. (1972). This may be a probable reason for increasing number of female flowers, decreasing number of male flowers and then by lowering sex ratio. Further it can be supported by the hypothesis suggested by Herrison (1957) that sexual differentiation is controlled by endogenous level of auxin in regions neightouring the flowering primordia and during the flowering formation of pistillate organs which may be favourd by high auxin level in the vicinity of differentiation primordia and of staminate organs by the low level. The above findings are in accordance with those of Pandya and Dixit (1997) on bottle gourd, Singh and Singh (1984) and Kshirsagar et al. (1995) on cucumber. The probable reason for increase the fruit length and diameter was due to respiration and photosynthesis of treated plants remained higher than the check (Audus, 1960). This may be due to greater accumulation of carbohydrates due to photosynthesis, which resulted in increasing weight and size of fruits. The another possible reason may be explained due of the report of Crane and Overbeek (1965) who stated that the sole function of fertilized ovules or seeds in relation to growth of fruit is to synthesis one or more hormones which initiate and maintaine a metabolic gradient along which foods can be translocated from the parts of the plants towards the fruits. These results are in agreement with those of Arora et al. (1987) on sponge gourd and Singh and Choudhury (1989) on bottle gourd and cucumber. Ethrel significantly increased the fruit yield over control. An increase in fruit yield in treated plants may further be attributed to that plants remain physiologyically more active to build up sufficient food stock for developing of flowers and fruits, hence leading to higher yield. The above results were in consonance with those of Pandy and Dixit (1997) on bottle gourd and Arora et al., (1987) on sponge gourd.

\section{Economic feasibility}

The economic evaluation of the experiments generally depends on the technical results of these experiments that have been applied, which had carried out in research stations and field experiments in different production areas, According to the results of the experiments related to the addition of growth regulators (ethrel and gibberellic acid) at different levels, And that was during two consecutive 
agricultural seasons (2016/2017) and (2017/2018), And it has been evident to increase the plant productivity of these transactions of growth regulators. (David, 1996).

However, there are several of indicators that must be taken in consideration when conducting the economic evaluation to estimate or predict the economic viability of these growth regulators, as these indicators usually reflect the economic efficiency of transactions, and the most important of these indicators are average productivity, total revenue, total costs, net revenue, Total revenue-to-cost ratio (the benefit-to-cost ratio, it equals the total monetary value of aggregate production to total feddan costs), Hinkelmann and Kempthorne, (2007) and Dean et al. (2015).

It is clear from data outlined in Table (9) that plants which treated ethrel at $100 \mathrm{ppm}$ for obtaining Feddan profit that it reached about 36.13 thousand pounds / feddan due to addition ethrel at $100 \mathrm{ppm}$ comparing with that gained from untreated plants (control) in $1^{\text {st }}$ season, Mosbah et al., (2019).

The results also indicated the preference of the treatment of ethrel at $100 \mathrm{ppm}$ on level of producing cost of the fruit, in addition to the ratio of the revenue to the costs compared to the control treatment, as well as the other transactions that depending on the feddan productivity for the treatment ethrel at $100 \mathrm{ppm}$.

As indicated from data outlined in Table (10), supplying plants ethrel at $100 \mathrm{ppm}$ in $2^{\text {nd }}$ season indicated an increase in feddan profitability at about 30.18 thousand pounds / feddan over its counterpart to the control treatment, That treatment is in relation to plant productivity and hence the percentage of its profit.

Table 9: Economic feasibility of ethrel $100 \mathrm{ppm}$ treatment compared to untreated plants (control) for $1^{\text {st }}$ season

\begin{tabular}{|c|c|c|c|c|c|c|c|c|}
\hline Transactions & $\begin{array}{c}\text { No. } \\
\text { Fruit/plant } \\
\\
\text { (Fruit } \\
\text { Yield) } \\
\end{array}$ & $\begin{array}{c}\text { No. } \\
\text { Fruit } \\
/ \\
\text { feddan }\end{array}$ & $\begin{array}{c}\text { Average } \\
\text { price of a } \\
\text { Fruit }\end{array}$ & $\begin{array}{c}\text { Total costs } \\
\text { (pounds / } \\
\text { feddan) }\end{array}$ & $\begin{array}{c}\begin{array}{c}\text { Total } \\
\text { revenue } \\
\text { (return) }\end{array} \\
\text { pounds } \\
\text { / feddan } \\
\end{array}$ & $\begin{array}{c}\text { Net } \\
\text { return } \\
\text { (profit) }\end{array}$ & $\begin{array}{l}\text { cost of per } \\
\text { a Fruit } \\
\text { (pounds }\end{array}$ & $\begin{array}{c}\text { Revenue / } \\
\text { cost (\%) }\end{array}$ \\
\hline ppm E 100 & 24.695 & 6420.7 & \multirow{2}{*}{10} & 28075 & 64207 & 36132 & 4.37 & 2.29 \\
\hline Control & 12.5 & 3250.0 & & 27655 & 32500 & 4845 & 8.51 & 1.18 \\
\hline $\begin{array}{l}\text { Deviation from } \\
\text { Control } \\
\end{array}$ & 12.195 & & & & 31707 & 31287 & -4.14 & 1.11 \\
\hline $\begin{array}{l}\text { Deviation from } \\
\text { (\%)Control }\end{array}$ & 97.56 & & & & & & -48.61 & 94.60 \\
\hline
\end{tabular}

Table 10: Economic feasibility of ethrel $100 \mathrm{ppm}$ treatment compared to untreated plants (control) for

\begin{tabular}{|c|c|c|c|c|c|c|c|c|}
\hline Transactions & $\begin{array}{c}\text { No. } \\
\text { Fruit/plant } \\
\text { (Fruit } \\
\text { Yield) } \\
\end{array}$ & $\begin{array}{l}\text { No. } \\
\text { Fruit/ } \\
\text { feddan }\end{array}$ & $\begin{array}{c}\text { Average } \\
\text { price of a } \\
\text { Fruit }\end{array}$ & $\begin{array}{c}\text { Total costs } \\
\text { (pounds / } \\
\text { feddan) }\end{array}$ & $\begin{array}{c}\text { Total revenue } \\
\text { (return) pounds / } \\
\text { feddan }\end{array}$ & $\begin{array}{c}\text { Net } \\
\text { return } \\
\text { (profit) }\end{array}$ & $\begin{array}{c}\text { cost of per a } \\
\text { Fruit } \\
\text { (pounds) }\end{array}$ & $\begin{array}{c}\text { Revenue } \\
\text { / cost } \\
(\%) \\
\end{array}$ \\
\hline ppm E 100 & 25.08 & 6520.8 & \multirow{2}{*}{10} & 28075 & 65208 & 37133 & 4.31 & 2.32 \\
\hline Control & 13.31 & 3460.6 & & 27655 & 34606 & 6951 & 7.99 & 1.25 \\
\hline $\begin{array}{l}\text { Deviation } \\
\text { from Control }\end{array}$ & 11.77 & & & & 30602 & 30182 & -3.69 & 1.07 \\
\hline $\begin{array}{l}\text { Deviation } \\
\text { from Control } \\
\text { (\%) }\end{array}$ & 88.43 & & & & & & -46.12 & 85.61 \\
\hline
\end{tabular}

The results also indicated the preference of the treatment of ethrel at $100 \mathrm{ppm}$ during the two seasons on level of producing cost of the fruit, in addition to the ratio of the revenue to the costs compared to the control treatment, as well as the other transactions that depending on the feddan productivity for the treatment ethrel at $100 \mathrm{ppm}$.

From the results of the economic indicators that were calculated to evaluate the treatment of ethrel at 100 ppm on level of the two consecutive agricultural seasons (2016/2017), (2017/2018), it was found that it achieved an feddan productivity exceeding other transactions, and it also achieved positive results at the level of the indicators mentioned in the tables above, whether from total feddan revenue, total profit, or revenue / cost (\%) compared to the control, and also the other transactions that depending on the per-feddan productivity for ethrel at $100 \mathrm{ppm}$. 
On other hand, the total area of luff crop in Egypt season 2017/2018 was about 2.87 thousand feddan Ministry of Agriculture and Land Reclamation, (2017/2018).

\section{Conclusion}

It is recommended from the aforementioned that to obtain the best growth and fruiting of Luffa cylindrical plant should be sprayed with ethrel at $100 \mathrm{ppm} 4$ times beginning from the transplant stage with 21 days interval.

\section{References}

Al-Khassawaneh, N.M., N.S. Karam and R.A. Shibli, 2006. 2006. Growth and flowering of black iris (Iris nigricans Dinsm.) following treatment with plant growth regulators. Sci Hortic., 107:187193.

Arora, S. K., M. L. Pantida and M. S. Dahiya, 1987. Effect of plant growth regulators on vegetative growth, flowering and yield of ridge gourd (Luffa acutangula Roxb) Haryona Agric. Univ. J. Res., 17(4): 319 - 324.

Asrey, R., G.N. Singh, H.S. Shukla, and R. Singh, 2001. Effect of seed soaking with Gibberellic acid on growth and fruiting of muskmelon (Cucumis melo L.). Haryana J Hort Sci., 30(3-4):277-278.

Audus, L.J., 1960. In "Encyclopedia of Plant Physiology" (ed L. Ruhland). Springer, Berlin, 3(2): 360 -387 .

Birader G,and C.M. Navalagatti, 2008. Effect of plant growth regulators on physiolog y and quality in bittergourd (Momordica charantia). MSc thesis, university of agricultural sciences, Dharwad.

Blake, C.A., 1965. Methods of Soil Analysis. Part I and II. Amer. Soc. Agron. in Pupl. Madison. Wise U.S.A.

Chauhan, J.S., YK Tomar, A. Badoni, N. Indrakumar, S. Seema, and A. Debarati, 2010. Morpholog y, germination and early seedling growth in Phaseolus mungo L. with reference to the influence of various plant growth substances. J Am Sci 6(1):34-41.

Crane, J.C. and J.V. Overbeek, 1965. Induction of parthenocarpy in figs by kinin. Sci., 147: 1468.

David, G.D., 1996. The Economic Evaluation of Projects", Papers from a Curriculum Development Workshop, Economic Development Institute of The World Bank.

Dean, A., M. Morris, J. Stufken, and D. Bingham, 2015. Handbook of design and analysis of experiments ", Chapman \& Hall/CRC handbooks of modern statistical methods.

Dewis, J. and F. Freitas, 1970. Physicological Methods of Soil and Water Analysis. Food and Agric. Organization of the United Nations of Soils Bulletin No. (10): 275.

Gad, A.A., A.A. Alsadon, and H.M. Wahdan,1993. Sex expression and yield response of summer squash to ethrel. Ann Agric Sci, Ani Shams Univ Cairo 38:251-259.

Herrison, H.J., 1957. The experiment modification of sex expression in flowering plants. Biol. Rev., 32: $38-90$.

Hilli, J.S. and B.S. Vyakaranahal, 2005. Studies on seed production and post-harvest techniques in ridge gourd (Luffa acutangula, L. Roxb). Ph. D. Thesis, University of Agricultural Sciences, Dharwad.

Hinkelmann, K. and O. Kempthorne, 2007. Design and Analysis of Experiments. Introduction to Experimental Design“, second edition, Wiley Series in Probability and Statistics.

Jamil, M.,and E.S. Rha, 2007. Gibberllic acid (GA3) enhance seed water uptake germination and early seedling growth in sugar beet under salt stress. Pak J Biol Sci 10(4):654-658.

John, M.K., 1970. Colorimetric determination of phosphorus in soil and plant materials with ascorbic acid. Soil Sci., 109 (4): 214 - 220

Korzeniewska, A.,and S.K. Niemirowiez,1993. Effect of ethrel on fruit and seed related characters in four inbred lines of Cucurbita maxima duch. Gatenbauwissenschaff 58:266-271

Kshirsagar, D.B., U.T. Desai, B.T. Partil, and B.G. Pawar, 1995. Effect of plant growth regulators on sex expression and fruiting in cucumber cv. Himangi J. Maharashtra agric. Univ., 20(3): $473-$ 474.

Ministry of Agriculture and Land Reclamation, Economic Affairs Sector, "Bulletin of Agricultural Statistics”, Part (2), Summer \& Nili Crops 2017/2018. 
Mosbah, M.K., E.E. Shaker, S.A. Ali and Hanan A. Zahran, 2019. An Analytical Study to Costs and Returns of the Egyptian Lupine Plant", $9^{\text {th }}$ International Conference for Sustainable Agricultural Development 4-6 March 2019 Fayoum J. Agric. Res,\&Dev.,Vol.33 No. 1(B) March.

Pandy, M.B. and C.K. Dixit, 1997. Effect of plant growth regulators on bottle gourd Lagenaria siceraria (Mol. Standl.) cv. PUSA Summer Prolificlong. J. Applied Hort., 3(2): 105 - 111

Part, L., C. Botti, and T. Fichet, 2008. Effect of plant growth regulators on floral differentiation and seed production in Jojoba (Simmondsia chinensis (Link) Schneider). Indus Crops Products 27:4449

Patel, H.B., D.K.Kakade, S.T. Rukam, G.U. Kulkarni, P.G. Memane, N.A. Deshmukh, J.S. Sharma and C.D. Patel, 2009. Effect of plant growth regulators on sex expression and yield of sponge gourd Luffa cylindrica (Roem) cv. PUSACHIKNI. The Asian Journal of Horticulture 4 (2): $108-110$.

Rudich, J.J., A.H. Harley, and N. Kedar, 1972. Ethylene evolution from cucumber plants as related to sex expression. Plant physiology. 49: 998-99.

Saric, M., R. Kastrori, R. Curei, T. Capina, and I. Geric, 1976. Chlorophyll determination. Univ. Unoveu sadu Parktikum is Fizologize Bibijoke, Beagard, Haunca, Anjiga, p125.

SAS, 1994. SAS ISTAT User's Guide; Statistics. Vers. 6. 04, $4^{\text {th }}$ ed SAS Institute Inc. Cary. N. C., USA.

Singh, G.P. and R.K. Singh, 1984. Chemical sex modification and its effect on fruiting in cucumber (Cucumis sativus, L.). South Indian. J. Hort., 32(3): 127 - 131.

Singh, R. K. and B. Choudhury, 1989. Different responses of three genera of cucurbits to boron and plant growth regulators, Indian. J. Hort., 46(2): 215 - 221.

Snedecor, N.W. and W.G. Cochran, 1980. Statistical Methods, $6^{\text {th }}$ ed. The Iowa State Univ. Press. Ames Iowa U.S.A.

Thappa, M., S. Kumar,and R. Rafiq, 2011. Influence of plant growth regulators on morphological, floral and yield traits of cucumber (Cucumis sativus, L.). Kasetsart J (Nat Sci) 45:177-188.

Vadiger, B.G., B.B. Madalageri, and M.N. Sheelavantar, 2001. Effect of ethrel and gibberellic acid on yield and quality of two cucumber varieties. Karnataka J Agric Sci., 14:727-730. 